Originalartikkel

\title{
Vekstkurver for norske barn
}

\begin{abstract}
Sammendrag
Bakgrunn. Dagens norske vekstreferanser ble innsamlet i 1970-80-årene. Det foreligger nye data fra Vekststudien i Bergen, innsamlet i 2003-06. Verdens helseorganisasjon (WHO) presenterte i 2006 en vekststandard for $0-5$ år gamle barn. Denne vurderes brukt i Norge.
\end{abstract}

Materiale og metode. På bakgrunn av dataene fra Vekststudien i Bergen presenterer vi vekstkurver for barn i alderen 0-19 år. Disse nye kurvene blir sammenliknet med dagens norske vekstkurver og WHOs vekststandard.

Resultater. Norske barn i alderen 0-4 år har i dag lengde/høyde og vekt som kun er marginalt forskjellig fra vekstkurvene som er i bruk. For eldre barn foreligger derimot en økning i 50-prosentilen for høyde med opptil $3,4 \mathrm{~cm}$ hos gutter og $2,5 \mathrm{~cm}$ hos jenter. For barn over fire år har vekten i forhold til høyden også økt - spesielt gjelder dette de øverste prosentilene. Kurvene for dagens norske barn ligger over WHOs vekststandard for fødselsvekt og lengde/høyde, vekt og hodeomkrets for aldersgruppen 6 md. -5 år.

Fortolkning. De påviste langsomme veksttrendene indikerer at det er behov for nye vekstkurver i Norge. Det at norske barn avviker fra WHOs vekststandard, kan gjenspeile forskjeller i omgivelsene eller ulikt vekstpotensial i forskjellige populasjoner.
Pétur B. Júlíusson

petur.juliusson@helse-bergen.no

Seksjon for endokrinologi og metabolisme Barneklinikken

Haukeland universitetssykehus 5021 Bergen

og

Institutt for klinisk medisin

Seksjon for pediatri

Universitetet i Bergen

\section{Mathieu Roelants}

Laboratory for Anthropogenetics

Vrije Universiteit Brussel

Brussel

\section{Geir Egil Eide}

Kompetansesenter for klinisk forskning

Haukeland universitetssykehus

og

Institutt for samfunnsmedisinske fag

Seksjon for epidemiologi og medisinsk statistikk Universitetet i Bergen

\section{Dag Moster}

Barneklinikken

Haukeland universitetssykehus

og

Locus for registerepidemiologi

Institutt for samfunnsmedisinske fag

Universitetet i Bergen

\section{Anders Juul}

Afdeling for Vækst og Reproduktion

Rigshospitalet

Københavns Universitet

\section{Roland Hauspie}

Laboratory for Anthropogenetics

Vrije Universiteit Brussel

Brussel

\section{Per Erik Waaler}

Barneklinikken

Haukeland universitetssykehus

\section{Robert Bjerknes}

Institutt for klinisk medisin

Seksjon for pediatri

Universitetet i Bergen

og

Barneklinikken

Haukeland universitetssykehus

Målinger av europeiske befolkningsgrupper har vist en langsom positiv trend i barns vekst - med en gradvis økning i slutthøyde på $0,3-3 \mathrm{~cm}$ for hver tiårsperiode $(1-3)$. Denne utviklingen skyldes i hovedsak bedre ernæring og gunstigere sosioøkonomiske forhold samt færre infeksjoner (4). I tillegg til å følge med på barns høydeutvikling vil det også være viktig å kartlegge utviklingen i vekt, spesielt med tanke på økt forekomst av overvekt hos barn og ungdom (5). Regelmessig oppdatering av nasjonale vekstreferanser sikrer at vekstkurver i klinisk bruk til enhver tid gjenspeiler den friske barne- befolkningen og er i tråd med helsemyndighetenes veiledninger (6). For å kontrollere for variasjonen som foreligger mellom befolkningsgrupper har det vært tradisjon å lage etnisk spesifikke og nasjonsspesifikke vekstreferanser. Den første norske vekstreferansen ble utarbeidet av Alfred Sundal i 1950-årene $(7,8)$, mens dagens referanser baserer seg på data innsamlet i 1970-80årene (9).

I årene 2003-06 ble det gjennomført målinger som ledd i Vekststudien i Bergen (BGS), en tverrsnittsstudie som inkluderte 8299 barn i alderen 0-19 år. En av målsettingene med studien var å samle referansedata som kunne danne grunnlag for utarbeiding av oppdaterte og klinisk relevante vekstkurver. De første analysene av innsamlede data viste at det hadde vært en klar økning $\mathrm{i}$ høyde, noe som indikerte et behov for oppdatering av eksisterende vekstkurver (10).

I 2006 lanserte Verdens helseorganisasjon (WHO) en vekststandard for barn i alderen $0-5$ år som ble anbefalt brukt internasjonalt (11). Utarbeidingen av disse kurvene, som inkluderte barn fra seks forskjellige land, deriblant Norge, er bl.a. basert på den hypotese at barn, under gode oppvekstvilkår, vokser likt de første leveårene, uavhengig av genetiske forhold (12). Disse kurvene er tidligere beskrevet i Tidsskriftet (13).

Hensikten med denne artikkelen er å presentere vekstkurver for barn i alderen 0-19 år basert på data fra Vekststudien i Bergen og Medisinsk fødselsregister samt sammen-

\section{Hovedbudskap}

- Norske skolebarn er generelt høyere i dag enn for 30 år siden. Utvikling av overvekt synes å ramme en undergruppe

- For norske barn i aldersgruppen 0-4 år har både fødselsvekt, lengde/høyde, vekt og hodeomkrets vært nokså uendret de siste 20 år

- Norske barn har høyere fødselsvekt, større lengde/høyde, større hodeomkrets og er tyngre sammenliknet med WHOs internasjonale vekststandard

- Hvilke vekstkurver som til enhver tid brukes i oppfølging og utredning av barn, har utredningsmessige og behandlingsmessige konsekvenser 


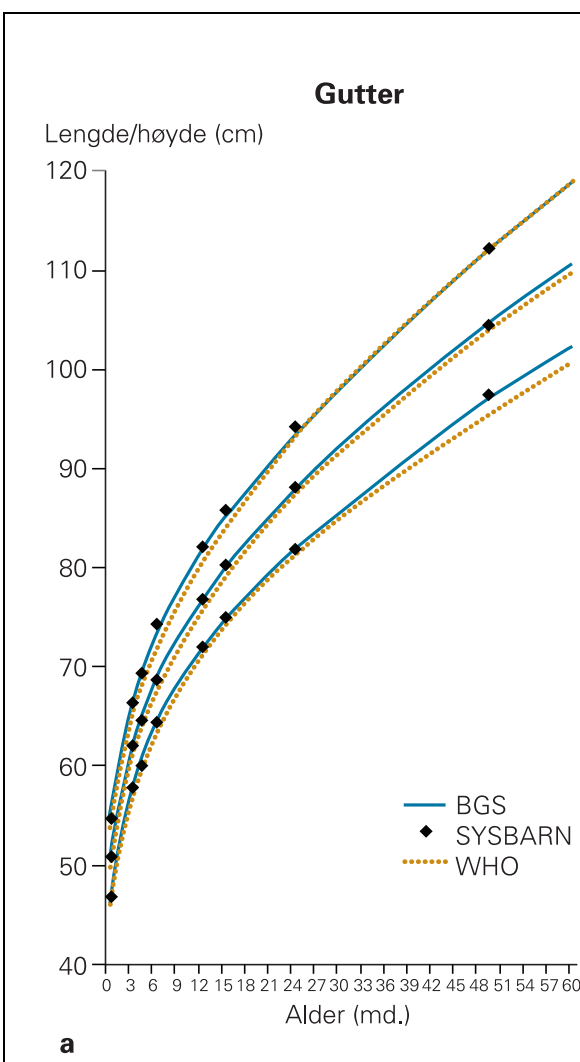

Figur 1 Sammenlikning av lengde/høyde mot alder mellom nye norske vekstkurver fra Vekststudien i Bergen (BGS), SYSBARN-undersøkelsen og WHOs internasjonale vekstkurver for al gutter og b) jenter $i$ alderen 0-5 år. Linjene viser 2,5-, 50- og 97,5-prosentilene

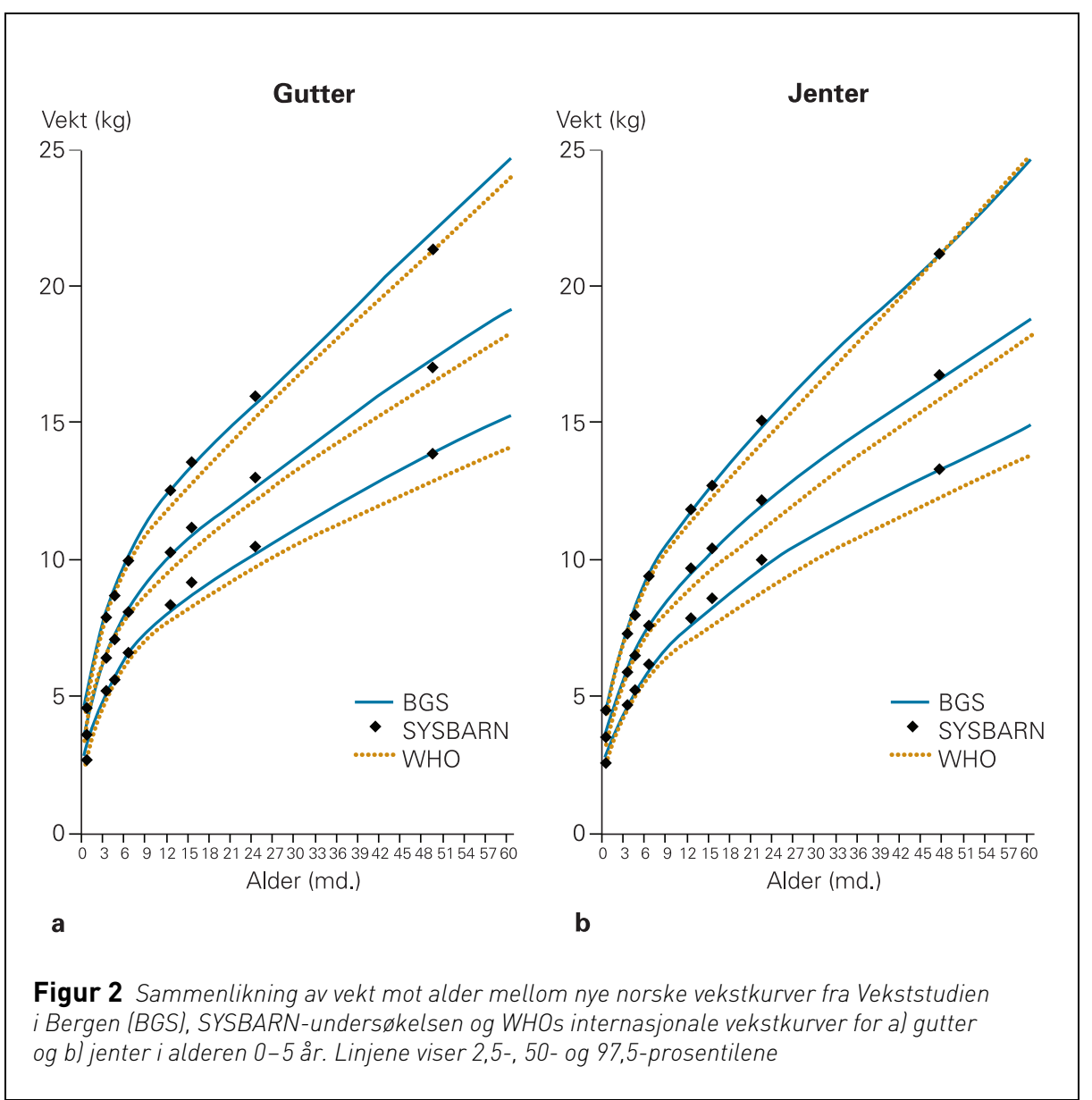

likne disse med dagens norske kurver og de internasjonale kurvene basert på WHOs vekststandard.

\section{Materiale og metode}

Vekststudien i Bergen

Barnepopulasjonen. I årene 2003-06 ble det gjennomført målinger som ledd i Vekststudien i Bergen, en tverrsnittsstudie som inkluderte 8299 barn i alderen 0-19 år bosatt i Bergen kommune. I datagrunnlaget for vekstkurvene ble 936 barn der en eller begge foreldre var fra land utenfor Norden og 85 barn med kronisk sykdom eller prematuritet ekskludert. Målinger fra totalt 7291 barn ble derfor brukt i arbeidet med kurvene - data fra 3756 gutter og 3535 jenter. Av disse var 2736 under fem år. Barna ble rekruttert fra Bergen kommune basert på tilfeldig stratifisert utvelgelse av helsestasjoner $(n=8)$, barnehager $(n=34)$ og skoler $(\mathrm{n}=24$, derav 19 barne- og/eller ungdomsskoler og fem videregående skoler). Alle barn ble invitert til å delta, men kun der det forelå skriftlig samtykke til deltakelse fra foreldrene og/eller barnet ble det målt. På helsestasjonene ble rundt $98 \%$ av tilgjengelige barn målt. Deltakelsen var på 57\% i barnehagene, $69 \%$ i barneskolene (1.-7. klassetrinn), $53 \%$ i ungdomsskolene (8.-10. trinn) og på $45 \%$ i de videregående skolene (1.-3. trinn). Fravær på grunn av deltidsplass i barnehagen, aktiviteter i barnehagen eller på skolen måledagen, reiser og sykefravær var faktorer som påvirket oppslutningen, i tillegg til at en del ikke ønsket å delta.

Ved utarbeiding av kurvene ble data for fødselsvekt, lengde ved fødselen og hodeomkrets hentet fra Medisinsk fødselsregister. Dette omfattet 12576 levendefødte barn som kom til verden i årene 1999-2003, uten misdannelser, med svangerskapsalder 37-42 uker og med mor bosatt i Bergen. Barnet skulle ikke være registrert med innvandrerbakgrunn. På vekstkurvene for alderen 4-19 år er det videre lagt inn referanser for pubertetsutvikling. Disse er basert på de nyeste tilgjengelige pubertetsdata fra Skandinavia og er bygd på undersøkelser av 1925 danske gutter og jenter i alderen 6-19,9 år fra Københavns-området, innsamlet i 1991-93 (14).

Målingene. Alle målinger ble utført med standardisert teknikk (15) av ni sykepleiere, tre helsesøstre og en barnelege. Målingene ble utført mellom kl. 0830 og 1300 og ført direkte inn i en database $i$ en bærbar datamaskin.

Kvalitetskontroll. Ved starten av hver måledag ble måleutstyr, høyde- og lengdemålere kontrollert. Personvektene på helsestasjonene ble kontrollert to ganger årlig, vektene på skolene eller i barnehagene hver gang de ble flyttet. To ganger årlig deltok alle medarbeiderne i en felles måleøkt, der ti barn ble målt to ganger av alle. Etterpå ble intra- og interobservatørsamsvar vurdert, bl.a. med beregning av tekniske målefeil (technical error of measurements) (16).

Statistiske analyser. Dataanalysene ble 
utført med programvarene SPSS 11.5 (2003, SPSS Inc., Chicago, IL) og R versjon 2.3.1 (2006, R Foundation for Statistical Computing, Wien). Kurvene ble utarbeidet ved hjelp av vekstmodellen LMS av Cole \& Green (17) og tegnet i R.

Etikk og godkjenninger. Vekststudien i Bergen er vurdert og klarert av regional komité for medisinsk og helsefaglig forskningsetikk i Vest-Norge, og det er innhentet konsesjon fra Datatilsynet.

\section{Tidligere norske vekstreferanser}

De første norske referansekurvene til Sundal hadde som utgangspunkt en tverrsnittsundersøkelse utført i Bergen i perioden 1950-56, der informasjon om lengde/høyde og vekt hos 17795 barn i alderen 0-17 år ble innsamlet (8). Det er ikke utført matematiske sammenlikninger med Sundals data $i$ denne artikkelen, men prosentilene vises i figurene for å illustrere trender i vekst.

Dagens norske kurver bygger på data fra 3-17 år gamle barn registrert i Bergen av Waaler i årene 1971-74 (18) og på data fra barn i alderen 0-4 år registrert i Oslo og Hedmark (SYSBARN-undersøkelsen) i årene 1982-84. I tillegg er det brukt data fra Medisinsk fødselsregister for samme tidsrom (19). I SYSBARN-undersøkelsen benyttet man data for lengde/høyde, vekt og hodeomkrets fra rutineundersøkelser i Oslo og Hedmark av 23669 barn i alderen 0-4 år (19). Waalers studie var en blandet longitudinell undersøkelse som inkluderte data for høyde, vekt og hodeomkrets hos 3068 barn i alderen 3-17 år. Høyde og vekt ble hos mange av disse målt opptil fire ganger $i$ året, totalt antall målinger i denne studien var derfor 8414 (18).

\section{WHOs vekststandard}

De internasjonale vekstkurvene fra WHO for alderen $0-5$ år er basert på målinger av 1687 norske barn samt barn fra Brasil, Ghana, India, Oman og USA, totalt 7551 barn (20). Ved innsamling av datamaterialet ble det lagt vekt på å redusere faktorer med kjent negativ påvirkning på veksten. Kriterier som gunstige sosioøkonomiske forhold, god ernæring (bare eller i hovedsak amming $i$ fire måneder og total ammeperiode på minst 12 måneder) og ikke-røykende mor måtte derfor være oppfylt (13).

\section{Sammenlikninger}

Våre vekstkurver for alderen 0-19 år ble sammenliknet med prosentilene fra SYSBARN-undersøkelsen (0-4 år), Waalers studie (4-17 år) og WHO-kurvene (0-5 år). Fordi dataene fra Sundals og Waalers studier ikke er utarbeidet ved hjelp av en vekstmodell, har disse prosentillinjene et noe ujevnt utseende i figurene. I SYSBARN-undersøkelsen er det rapportert ni måletidspunkter for barn i alderen 0-49 måneder. Sundal og Waaler rapporterte årsintervaller, og dataene fra Vekststudien i Bergen og WHO brukt her har månedsintervaller. Det ble gjort sammenlik-
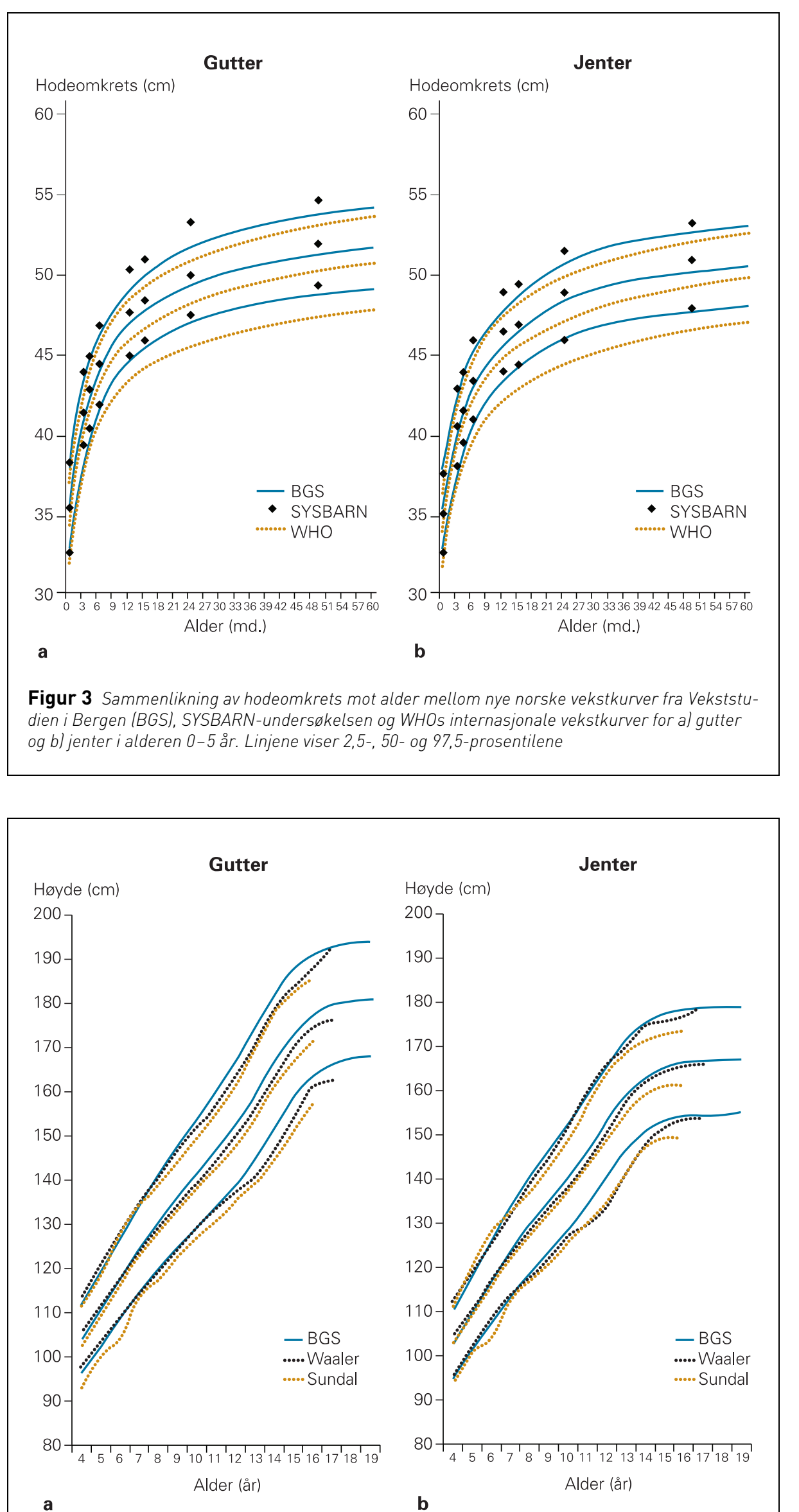

Figur 4 Sammenlikning av høyde mot alder mellom Sundals studie, Waalers studie og nye norske vekstkurver fra Vekststudien i Bergen (BGS) for al gutter og b) jenter i alderen 4-19 år. Linjene viser 2,5-, 50- og 97,5-prosentilene 


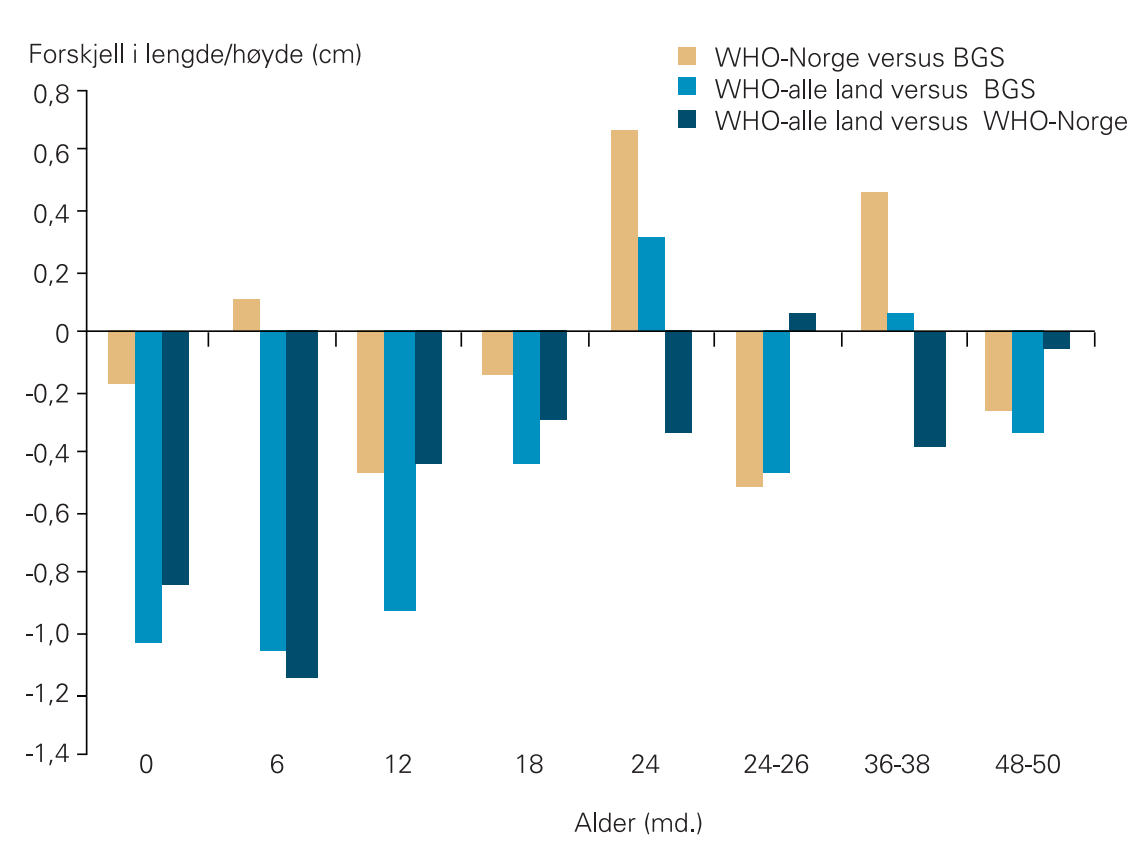

Figur 5 Forskjell i gjennomsnittlig lengde mellom nye norske vekstkurver fra Vekststudien i Bergen (BGS), de norske barna som inngikk i WHO-materialet (WHO-Norge) og de samlede WHO-verdiene (WHO-alle land). Forskjellene ved 24 måneder og ved 24-26 måneder er påvirket av forskjellig måte å behandle overgangen fra liggende lengde til stående høyde, og dataene her er derfor ikke sammenliknbare. Kjønnene er her fremstilt samlet

ning av fødselsvekt og 2,5-, 50- og 97,5-prosentilene for de aktuelle kurvene. For sammenlikning av vekt mot høyde ble tallmateriale fra Vekststudien i Bergen brukt (21).

Kurvene fra WHO har et lite hakk ved to års alder, det viser reduksjonen i kroppslengde når man går fra å måle liggende lengde til stående høyde (11). I Norge og mange andre land har man sett bort fra dette. Derfor er kurvene ikke sammenliknbare for intervallet fra ca. tre måneder før og til ca. tre måneder etter to års alder.

\section{Resultater}

Vi utarbeidet nye prosentilkurver for alderen 0-12 måneder (hhv. hodeomkrets, lengde og vekt mot alder), 1-5 år (hhv. hodeomkrets, lengde/høyde og vekt mot alder), 4-19 år (hhv. høyde og vekt mot alder) og 2-19 år (kroppsmasseindeks (BMI) mot alder). Samtlige kurver finnes på www.tidsskriftet.no/ juliussonappendiks. På kurvene ble det lagt inn grå felter som definerer området mellom $+2,0$ til $+2,5$ standardavvik (SD) og området mellom $-2,0$ til $-2,5$ standardavvik. På BMIkurven ble det angitt grenseverdier for overvekt, fedme og undervekt.

\section{Sammenlikning med dagens}

norske kurver - 0-4 år

Fødselsvekt. Gjennomsnittlig fødselsvekt for gutter i SYSBARN-undersøkelsen var $3600 \mathrm{~g}$, mens den for de nye kurvene var $3710 \mathrm{~g}$. Tilsvarende verdier for jenter $\mathrm{i}$ SYSBARN-undersøkelsen var $3500 \mathrm{~g}$ og for de nye kurvene $3580 \mathrm{~g}$.

Lengde/høyde (fig 1). De nye kurvene vis- te helt minimale endringer i lengde/høyde sammenliknet med SYSBARN-undersøkelsen.

Vekt (fig 2). Ved sammenlikning med data fra SYSBARN-undersøkelsen lå de nye kurvene for 15 og 24 måneder gamle barn under disse. Forskjellen var størst hos 15 måneder gamle gutter, den var da på 0,4 kg (2,5-prosentilen). For de andre målepunktene var verdiene sammenliknbare, med unntak av 97,5-prosentilen for 49 måneder gamle gutter, hvor SYSBARN lå $0,6 \mathrm{~kg}$ under de nye kurvene.

Hodeomkrets (fig 3). Ved sammenlikning av de nye hodeomkretskurvene med data fra SYSBARN-undersøkelsen lå de nye kurvene under for alle prosentiler. Forskjellene for gutter er størst i aldersgruppen 3 md. -2 år: 1,0 $\mathrm{cm}, 0,8 \mathrm{~cm}$ og 1,6 cm for henholdsvis 2,5-, 50og 97,5-prosentilen. For jenter er forskjellene størst i aldersgruppen 4 md. -2 år: $0,8 \mathrm{~cm}$, $0,9 \mathrm{~cm}$ og 1,2 $\mathrm{cm}$ for henholdsvis 2,5-, 50- og 97,5-prosentilen.

\section{Sammenlikning med dagens} norske kurver - 4-17 år

Høyde (fig 4). Ved sammenlikning av våre data og Waalers data fremkom det en gjennomsnittlig økning i høyde på $0,9 \mathrm{~cm}$ hos gutter og 0,6 cm hos jenter. Prosentilene i de nye kurvene lå høyere enn Waalers data, med unntak av hos barn under 6-7 år. Forskjellene var størst i øvre barnealder og i ungdomsårene. Differansen i 50-prosentilen for høyde var opptil 3,4 cm hos gutter og 2,5 $\mathrm{cm}$ hos jenter. For 2,5-prosentilen var forskjellene størst i puberteten, med differanser på opptil hele $4,5 \mathrm{~cm}$ hos guttene og hele 7 $\mathrm{cm}$ hos jentene. Prosentilene fra Sundals materiale er også lagt inn i figur 3 for å vise trendene i høydeutvikling.

Vekt. I vårt materiale lå $8 \%$ av guttene og $7,2 \%$ av jentene i alderen $4-15$ år over 97,5prosentilen for vekt mot høyde i Waalers studie (21). Det er ikke gjort noen sammenlikninger av kurvene for vekt mot alder fordi disse er påvirket av høydeutviklingen $\mathrm{i}$ tidsperioden.

\section{Sammenlikning med WHOs standard for aldersgruppen 0-5 år}

Fødselsvekt. Gjennomsnittlig fødselsvekt i WHO-studien var $3300 \mathrm{~g}$ for gutter og $3200 \mathrm{~g}$ for jenter, dvs. henholdsvis $410 \mathrm{~g}$ og $380 \mathrm{~g}$ lavere enn $\mathrm{i}$ vår studie. For de norske barna i WHO-studien var gjennomsnittlig fødselsvekt for kjønnene samlet $(52,4 \%$ gutter) på $3640 \mathrm{~g}$. Tilsvarende tall fra Medisinsk

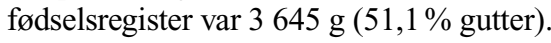

Lengde/høyde (fig 1). Sammenliknet med WHO-kurvene ligger barna i vår studie over i lengde/høyde for alle aldersgrupper, med unntak av 97,5-prosentilen for høyde mot alder for barn over tre år. Når det gjelder henholdsvis gutter og jenter i alderen $2-5$ år, faller gjennomsnittlig $1,2 \%$ og $1,3 \%$ under $-2,0$ standardavvik, SD (2,3-prosentilen) på WHOkurven for lengde/høyde mot alder. Forskjellen er opptil 1,2 cm for gutter (49 md.) og 1,1 $\mathrm{cm}$ for jenter (hhv. $16 \mathrm{md}$. og $60 \mathrm{md}$.). Tilsvarende ligger $2,2 \%$ av guttene og $2,1 \%$ av jentene over +2,0 SD (97,7-prosentilen) i WHOmaterialet. Det er videre verdt å merke seg at veksten til de norske barna som ble inkludert $\mathrm{i}$ WHO-studien er likere våre kurver enn det samlede datamaterialet fra denne. Spesielt gjelder dette de to første leveårene (fig 5).

Vekt (fig 2). Med unntak av fødselsvekten er vektutviklingen nokså lik opp til seks måneders alder. Deretter blir de nye kurvene liggende over WHO-vekstkurven - med unntak av 97,5-prosentilen for eldre jenter, der linjene krysser hverandre. Når det gjelder gutter og jenter i alderen 2-5 år, faller henholdsvis gjennomsnittlig $0,45 \%$ av guttene og $0,27 \%$ av jentene under verdiene for $-2,0$ SD (2,3-prosentilen) fra WHO. Forskjellen er opptil 1,0 kg for gutter (49 md.) og $1,1 \mathrm{~kg}$ for jenter $(60 \mathrm{md}$.). Tilsvarende ligger $3,8 \%$ av guttene og $3,2 \%$ av jentene over +2,0 SD (97,7-prosentilen) til WHO. Da WHO ikke har publisert data for vekt fra hvert enkelt deltakerland, er det ikke mulig å sammenlikne de norske vektdataene fra WHO-studien med våre resultater. Eksklusjon av de tyngste barna i WHO-studien gjør også sammenlikning vanskelig (22).

Hodeomkrets (fig 3). WHO-kurven ligger klart under våre kurver for alle prosentiler. Forskjellene for gutter er størst ved to års alder: $1,5 \mathrm{~cm}, 1,2 \mathrm{~cm}$ og $0,8 \mathrm{~cm}$ for henholdsvis 2,5-, 50- og 97,5-prosentilen. Nesten ingen gutter i vårt materiale faller under 2,5-prosentilen fra WHO, og 6,9\% ligger over $+2,0 \mathrm{SD}$ (97,7-prosentilen). For jenter er forskjellene også størst ved to års alder: $1,6 \mathrm{~cm}, 1,3 \mathrm{~cm}$ og 
0,9 cm for henholdsvis 2,5-, 50- og 97,5-prosentilen. Nesten ingen jenter faller under 2,5prosentilen til WHO, og 5,3\% ligger over $+2,0$ SD (97,7-prosentilen). WHO har ikke publisert data for hodeomkrets fra hvert enkelt deltakerland.

\section{Diskusjon}

De nye dataene fra Vekststudien i Bergen viste klare tendenser i retning av økt høyde og vekt hos skolebarn, mens for aldersgruppen 0-4 år har både fødselsvekt, lengde/ høyde og vekt vært nokså uendret de siste vel 20 år. Dagens norske barn har klart høyere fødselsvekt sammenliknet med barn i det samlede datamaterialet fra WHO, og var også med få unntak både lengre og tyngre og hadde større hodeomkrets.

Den observerte trenden i lengdevekst hos norske skolebarn er som forventet ut fra utviklingen $i$ andre europeiske land i samme tidsperiode $(2,23)$. En slik langsomtøkende høydeutvikling har vært relatert til bedre ernæring, færre infeksjoner og gunstigere sosioøkonomiske forhold og kan foregå over mange generasjoner inntil avflatning (2). Avflatningen i høydeutvikling hos vernepliktige de siste to tiårene (24) tyder på at den norske befolkningen kan være i ferd med å oppnå sitt genetiske potensial for vekst. Lengdeveksttrenden som er observert fra 1970-årene gjenspeiler likevel behovet for oppgraderte vekstkurver for bruk i Norge.

Hodeomkretsen ble målt noe større SYSBARN-undersøkelsen enn i Vekststudien i Bergen. I fravær av endringer i lengde/ høyde eller vekt er det mulig at forskjeller i måleteknikk kan forklare denne observerte differansen. I SYSBARN-undersøkelsen analyserte man rutinemålinger utført av mange forskjellige, mens målingene i Vekststudien i Bergen ble utført av noen få personer med standardisert måleteknikk.

Den gjennomsnittlige menarkealderen i Vekststudien i Bergen (13,25 år $\pm 1,05$ år) er uforandret sammenliknet med det man fant $\mathrm{i}$ tidligere norske studier (3). Selv om amerikanske data har gitt mistanke om tidligere pubertetsstart enn før (25), har europeiske studier hittil ikke kunnet bekrefte dette (14, 26). Uforandret gjennomsnittlig menarkealder hos norske barn tyder på at større høyde i barnealderen ikke skyldes tidligere modning, selv om man ikke kan utelukke en mulig tidligere start og samtidig langsommere progresjon. Dataene for pubertetsutviklingen hos danske barn, som er innarbeidet $i$ våre kurver, er på samme nivå som det man fant i en dansk studie fra 1964 (14).

Det var kun marginale forskjeller i vekt mot alder mellom studien til Sundal fra 1950årene og Waalers studie fra 1970-årene (18). De siste par tiårene har det funnet sted en bekymringsfull økning i overvekt og fedme hos barn og ungdom internasjonalt (5). I vårt tallmateriale finner vi imidlertid vektøkning kun hos dem over fem år, og da er det først og fremst de tyngste barna som er blitt tyngre, dvs. at de øverste prosentilene er mest påvirket (21). Økt overvekt rammer derfor mest én gruppe i barnepopulasjonen. Utviklingen i overvekt krever tiltak på mange plan, ikke minst en fornuftig generell helsepolitikk (27). De nevnte funn taler imidlertid for at målrettede tiltak rettet mot spesielle grupper i barnepopulasjonen kanskje vil være noe av det som det haster mest å komme i gang med.

Økt høyde hos eldre barn gjør det viktig å oppgradere kurvene, men økning i vekt gjør det også viktig å anvende kurver som er funksjonelle å bruke overfor problemstillingen overvekt og fedme. En rasjonell måte for oss i Norge er å bruke BMI-kurver med innlagte grenseverdier for overvekt og fedme. På denne bakgrunn er det utarbeidet slike kurver der det er lagt inn internasjonalt anerkjente grenseverdier for henholdsvis overvekt og fedme som foreslått av International Obesity Task Force (IOTF) (28). Dette er robuste linjer som ikke endres med langsomme trender.

Etter vår oppfatning foreligger det også klinisk relevante forskjeller mellom den nye norske vekstreferansen og WHOs vekststandard. Gjennomsnittlig fødselsvekt for dagens norske gutter og jenter ligger henholdsvis $410 \mathrm{~g}$ og $380 \mathrm{~g}$ over angitt fødselsvekt fra WHO. De norske barna i WHO-studien hadde likevel - ikke overraskende - den samme fødselsvekten som barna i vår studie. Den lave fødselsvekten i de andre deltakerlandene drar ned den gjennomsnittlige fødselsvekten i WHO-studien $(20,29)$.

De nye vekstkurvene for norske barn viser noe større høyde enn WHO-standarden. Lengdeveksten til de norske deltakerbarna i WHO-studien følger likevel et vekstmønster de første to leveår som er likere våre vekstkurver enn vekstkurvene $\mathrm{i}$ den samlede WHO-studien.

Sammenlikning av vektdata mellom Vekststudien i Bergen og WHOs tall er vanskelig fordi vektdata fra det enkelte deltakerland ikke er publisert og fordi de tyngste barna ble ekskludert fra datamaterialet i WHO-studien (22).

Prosentilene for hodeomkrets i WHO-studien ligger konsekvent under den nye vekstreferansen. Forskjellene er enda større mellom SYSBARN-undersøkelsen og WHOdataene. Metodemessig er målingene for hodeomkrets utført på lik måte i Vekststudien i Bergen og WHO-studien.

Forskjellene i lengdevekst, hodeomkrets og kanskje også vekt indikerer en utfordring for WHO-studiens hypotese om at alle barn vokser likt gitt gode oppvekstvilkår $(11,30)$, noe som er i tråd med den debatten som har gått internasjonalt om WHO-kurvene fullt ut kan erstatte nasjonale referanser (30).

Som de tidligere norske vekstkurvene gjelder også de nye barn av etnisk norsk opprinnelse. Det gjenstår å sammenlikne dem med barna i Vekststudien i Bergen med annen etnisk bakgrunn. Årsaken til at vi har valgt å lage kurver kun for etnisk norske barn er at forskjellene mellom etniske grupper er store, med forhøyet slutthøyde på opptil $7 \mathrm{~cm}$ i befolkningsgrupper med gode oppvekstvilkår $(31,32)$.

Det er viktig at det til enhver tid er tilgjengelig oppdaterte og representative vekstkurver for den friske barnebefolkningen. Det har definisjonsmessige og utredningsmessige konsekvenser hvor prosentillinjene ligger - særlig gjelder dette de øverste og de nederste prosentilene. Flere av forskjellene vi har påvist i denne artikkelen, ved sammenlikning med både tidligere norske vekstreferanser og med WHOs internasjonale vekststandard, er etter vår oppfatning klinisk relevante. For å hindre at barn utsettes for unødige utredninger og bekymringer er det viktig at det i Norge utarbeides oppdaterte faglige anbefalinger på dette området.

\section{Konklusjon}

Norske skolebarn er høyere og tyngre i dag enn det skolebarna var i 1970-årene. Utviklingen mot økt overvekt rammer mest en undergruppe av barnebefolkningen. Hos barn under fem år har det ikke vært store endringer i lengde/høyde eller vekt siden tidlig i 1980-årene. At norske barn avviker i fødselsvekt, lengde/høyde, vekt og hodeomkrets fra WHO-vekstkurvene, kan gjenspeile forskjeller i omgivelser eller forskjellig vekstpotensial populasjonene imellom.

Vi takker de involverte helsestasjonene, barnehagene og skolene. Spesiell takk rettes til barn og unge som deltok i studien og deres foresatte. Vi takker også Grethe Almenning, Linda Glomset, Janicke Hetland, Anita Hofstad, Marthe Holmgard, Eygló Jónsdóttir, Beate Nilsen, Margit Pedersen, Hilde Sælensminde, Sigrid Vinsjansen, Randi Vågset, Gerd-Anne Wincentsen og Kjersti Gunnleiksrud Ystgård for godt utført målearbeid. Vekststudien i Bergen har fått støtte fra Samarbeidsorganet Helse-Vest RHF og Universitetet i Bergen samt Novo Nordisk og Merck Serono.

Oppgitte interessekonflikter: Ingen

\footnotetext{
Litteratur

1. Cole TJ. Secular trends in growth. Proc Nutr Soc 2000: 59: 317-24.

2. Hauspie RC, Vercauteren M, Susanne C. Secular changes in growth and maturation: an update. Acta Paediatr Suppl 1997; 423: $20-7$

3. Liestol K, Rosenberg M. Height, weight and menarcheal age of schoolgirls in Oslo - an update. Ann Hum Biol 1995; 22: 199-205.

4. Schell L, Knutsen KL. Environmental effects on growth. I: Cameron N, red. Human growth and development London: Academic Press, 2002: 165-95.

Lobstein T. Frelut ML. Prevalence of overweight among children in Europe. Obes Rev 2003; 4: 195-200.

6. Patel L. Normal and distorted growth. I: Brook CGD, Clayton PE, Brown RS, red. Brook's Clinical pediatric endocrinology. Oxford: Blackwell, 2005: 90-123.

. Sundal A. Hodets største omkrets hos barn fra fødselen til syv års alder. Tidsskr Nor Lægeforen 1949: 69: 688-9.

8. Sundal A. The norms for height (length) and weight in healthy Norwegian children from birth to 15 years of age. Doktoravhandling. Bergen: Universitetet i Bergen, 1957.
} 
9. Knudtzon J, Waaler PE, Skjaerven R et al. Nye norske percentilkurver for høyde, vekt og hodeom krets for alderen 0-17 år. Tidsskr Nor Lægeforen 1988; 108: 2125-35

10. Juliusson P, Eide G, Roelants M et al. Secular changes in height and weight among Norwegian children: the Bergen Growth Study. 34th Congress of European Society of Paediatric Endocrinology (ESPE) 2005, Lyon. Horm Res 2005; 64 (suppl 1): 191.

11. WHO Child Growth Standards based on length/ height, weight and age. Acta Paediatr Suppl 2006; 450: $76-85$.

12. Assessment of differences in linear growth among populations in the WHO Multicentre Growth Refer ence Study. Acta Paediatr Suppl 2006; 450: 56-65.

13. Bærug AB, Tufte E, Norum KR et al. Verdens helseorganisasjons nye vekststandard for barn under fem år. Tidsskr Nor Lægeforen 2007; 127: $2390-4$

14. Juul A, Teilmann G, Scheike T et al. Pubertal development in Danish children: comparison of recent European and US data. Int J Androl 2006: 29: 247-55.

15. Juliusson P, Vinsjansen $S$, Nilsen B et al. Måling av vekst og vekt: en oversikt over anbefalte teknikker Pediatrisk Endokrinologi 2005; 19: $23-9$.

16. Standardisation procedures for the collection of weight and height data in the field. Measuring change in nutritional status. Genève: WHO, 1983 $41-5$
17. Cole TJ, Green PJ Smoothing reference centile curves: the LMS method and penalized likelihood. Stat Med 1992; 11: 1305-19.

18. Waaler PE. Anthropometric studies in Norwegian children. Acta Paediatr Scand Suppl 1983; 308: $1-41$

19. Knudtzon J, Waaler PE, Solberg LK et al. Høyde, vekt og hodeomkrets hos $0-4$ år gamle barn. Tidsskr Nor Lægeforen 1988; 108: 2136-42.

20. Enrolment and baseline characteristics in the WHO Multicentre Growth Reference Study. Acta Paediatr Suppl 2006; 450: 7-15.

21. Juliusson P, Roelants M, Eide G etal. Overweight and obesity in Norwegian children: secular trends in weight-for-height and skinfolds. Acta Paediatr 2007; 96: 1333-7.

22. WHO Child Growth Standards: methods and development. Genève: WHO, 2006.

23. Fredriks AM, van Buuren S, Burgmeijer RJ et at. Continuing positive secular growth change in The Netherlands 1955-1997. Pediatr Res 2000; 47 $316-23$.

24. Statistisk årbok 2007. Vernepliktige etter høyde. Oslo: Statistisk sentralbyrå, 2008. www.ssb.no/ aarbok/2007/tab/tab-106.html (14.1.2008).

25. Herman-Giddens ME, Slora EJ, Wasserman RC et al. Secondary sexual characteristics and menses in young girls seen in office practice: a study from the Pediatric Research in Office Settings network. Pediatrics 1997; 99: 505-12.
26. MuL D. Fredriks AM, van Buuren S et al. Pubertal development in The Netherlands 1965-1997. Pediatr Res 2001; 50: 479-86.

27. Lobstein T, Baur L, Uauy R. Obesity in children and young people: a crisis in public health. Obes Rev 2004; 5 (suppl 1): 4-104

28. Cole TJ, Bellizzi MC, Flegal KM et al. Establishing a standard definition for child overweight and obesity worldwide: international survey. BMJ 2000; 320: $1240-3$

29. Wright C, Lakshman R, Emmett P et al. Implications of adopting the WHO 2006 Child Growth Standard in the UK: two prospective cohort studies. Arch Dis Child 2008; 93: 566-9.

30. van Buuren S, van Wouwe JP. WHO Child Growth Standards in action. Arch Dis Child 2008: 93: 549-51.

31. Butte NF, Garza C, de Onis M. Evaluation of the feasibility of international growth standards for school-aged children and adolescents. J Nutr 2007; 137: 153-7.

32. Haas JD, Campirano F. Interpopulation variation in height among children 7 to 18 years of age. Food Nutr Bull 2006; 27: S212-23.

Manuskriptet ble mottatt 14.1. 2008 og godkjent 15.10. 2008. Medisinsk redaktør Åslaug Helland. 